\title{
In-situ microphysical characterization of low-level clouds in the Finnish sub-Arctic, extensive dataset.
}

Konstantinos Matthaios Doulgeris ${ }^{1}$, Heikki Lihavainen ${ }^{1,3}$, Anti-Pekka Hyvärinen ${ }^{1}$, Veli-Matti Kerminen ${ }^{2}$ and David Brus ${ }^{1}$

$5 \quad{ }^{1}$ Finnish Meteorological Institute, Erik Palménin aukio 1, P.O. Box 503, FIN-00100 Helsinki, Finland

${ }^{2}$ Institute for Atmospheric and Earth System Research/Physics, Faculty of Science, University of Helsinki, Helsinki, Finland

${ }^{3}$ Svalbard Integrated Arctic Earth Observing System (SIOS), SIOS Knowledge Centre, Svalbard Science Centre,

P.O. Box 156, N-9171 Longyearbyen, Norway

Correspondence to: K.D (Konstantinos.doulgeris@ fmi.fi)

10 Abstract. Continuous, semi-long-term, ground based in-situ cloud measurements were conducted during eight Pallas Cloud Experiments (PaCE) held in autumns between 2004 and 2019. Those campaigns were carried out in the Finnish sub-Arctic region at the Sammaltunturi station $\left(67^{\circ} 58^{\prime} 24^{\prime \prime} \mathrm{N}, 2^{\circ} 06^{\prime} 58^{\prime \prime} \mathrm{E} ; 560 \mathrm{~m} \mathrm{MSL}\right)$, the part of Pallas Atmosphere - Ecosystem Supersite and Global Atmosphere Watch (GAW) program. Two cloud spectrometer ground setups and a weather station were installed on the roof of the station to measure in-situ cloud properties and several meteorological variables. Thus, the obtained data sets include the size distribution of cloud droplets as a measured cloud parameter along with the temperature, dew point temperature, humidity, pressure, wind speed and direction, (global solar) sun radiation and visibility at the station. Additionally, the number concentration, effective diameter, median volume diameter and liquid water content from each instrument were derived. The presented data sets provide a great insight into microphysics of low-level clouds in sub-Arctic conditions over a wide range of temperatures (includes cloud cases with temperature from -25.8 to $8.8^{\circ} \mathrm{C}$ ). The data are available from the FMI open data repository for each campaign and each cloud spectrometer ground setup individually: https://doi.org/10.23728/FMI-B2SHARE.988739D21B824C709084E88ED6C6D54B (Doulgeris et al.,2021)

\section{Introduction}

Clouds are considered as a major component of both the climate system and the hydrological cycle. Nevertheless, our level of understanding of the fundamental details of the clouds microphysical processes is still very limited (Boucher et al., 2013). To gain a deeper knowledge of the formation and development of the clouds more in-situ measurements are needed (Morrison et al., 2019). In addition, a correct representation of cloud microphysics in general circulation models for numerical weather and climate prediction is of great importance (Guichard and Couvrex, 2017). Despite that cloud processes can now be studied with much more confidence (Bony et al., 2015), representing the formation and evolution of cloud droplets and the effects of aerosols on clouds at cloud droplets are considered as key parameters for a quantitative microphysical description of clouds (e.g., Rosenfeld and Ulbrich, 2003; Komppula et al., 2005; Lihavainen et al., 2008, Pruppacher and Klett, 2010, Chang et al., 2019), and are connected with the cloud lifetime and radiative effects as well the rain formation properties of clouds (e.g., Albrecht 1989; Devenish et al., 2012, McFarguhar et al., 2020).

Three general approaches were used in previous investigations for cloud microphysical properties: in-situ sampling through airborne measurements by aircrafts (e.g. Heymsfield et al., 2011; Craig et al., 2014; Petäjä et al., 2016) and recently, by Unmanned Aerial Systems (UASs) (e.g. Girdwood et al., 2020; Brus et al., 2021; Harrison et al., 2021); in-situ sampling by using laboratory cloud chambers (e.g. Möhler et al., 2003; Stratmann et al., 2004; Nichman et al., 2017; Doulgeris et al., 2018) and in-situ ground based measurements (e.g. Guyot et al., 2015; Lloyed et al., 2015; Lowenthal et al., 2019; Doulgeris et al., 2020). In-situ airborne and ground measurements (Wandinger et al., 2018) using cloud spectrometers are considered fundamental as they offer instrumental 
access to individual droplets within a sampling volume. However, employing any of the above approaches tackle their own difficulties.

Data sets that have been obtained from measurements in Arctic clouds are significant as cloud processes are considered as an important component to investigate the climate change in the Arctic region (Wendisch et al., 2019). Pallas Cloud Experiments (PaCE) took place in the Finnish sub-Arctic. Our main objective during PaCE was to study low-level clouds and their microphysical properties in a background sub-arctic environment. In this work, we present a unique dataset of ground in-situ cloud measurements along with several meteorological variables collected at the Sammaltunturi station in eight autumn campaigns conducted between 2004 and 2019. This data set can be used as complementary in investigating cloud microphysics, evaluation and improvement of the models. In further text, we provide the description of the measurement site, the instrumentation, the measurement methodology that was used for the data processing and the quality control.

\section{Methods}

\subsection{Measurement site and PaCE campaigns overview}

The measuring site was the Sammaltunturi station $\left(67^{\circ} 58^{\prime} 24^{\prime \prime} \mathrm{N}, 24^{\circ} 06^{\prime} 58^{\prime \prime} \mathrm{E}\right)$; it is hosted by the Finnish Meteorological Institute (FMI) and is located on a top of an arctic fjell (560 $\mathrm{m}$ above MSL) in the Finnish sub-Arctic region inside the PallasYllästunturi National Park (Fig. 1). The Pallas area is located around $180 \mathrm{~km}$ above the Arctic circle, and it has no significant local or regional air pollution sources. Thus, the Sammaltunturi station provides an excellent location for the monitoring of the background air composition in northern Europe. The station is about $100 \mathrm{~m}$ above the tree line and the vegetation around it consists mainly of low vascular plants, mosses, and lichen. There is a long history of atmospheric data collection in the area (Lohila et al. 2015) Monitoring activities of atmospheric composition at Sammaltunturi started in 1991 in a building that originally served the Finnish Broadcasting Company. The new station (102 $\left.\mathrm{m}^{2}\right)$ opened in July 2001. Since 1994, Sammaltunturi has been established as a node of the Pallas-Sodankylä supersite that contributes to the GAW program of the World Meteorological Organization. The site was descripted in detail in Hatakka et al. 2003. The main research measurements focus on greenhouse gas concentration, climate effects of atmospheric aerosols, aerosol cloud interaction and air quality (e.g., Komppula et al., 2005; Lihavainen et al., 2008; Asmi et al., 2011; Backman et al., 2017; Doulgeris et al., 2020). The predominant origin of air masses arriving at Sammaltunturi is usually from the Arctic (Asmi et al., 2011).

The main motivation to perform in-situ cloud measurements at the Sammaltunturi was that the station was occasionally inside a cloud. Based on analytical data the most suitable time of the year for in-situ cloud measurements was autumn because the horizontal visibility was below $1 \mathrm{~km}$ around $40 \%$ of the time (Hatakka et al. 2003). Thus, we started to conduct ground-based insitu measurements and study cloud formation. The "Pallas Cloud Experiments" were usually 6-8 weeks long and lasted approximately from the beginning of September until the end of November, occasionally to the beginning of December. The first attempt of measuring in situ cloud properties was made in 2004 using the forward-scattering spectrometer probe (FSSP-100) ground setup that was the only available cloud spectrometer at that time. The next campaigns, in 2005 and 2009, were done using the same instrument setup (Lihavainen et al., 2008). Later, in 2011 the cloud, aerosol and precipitation spectrometer (CAPS) ground setup (includes two instruments; the cloud and aerosol spectrometer (CAS) and the cloud imaging probe (CIP)) was purchased and during January and February 2012, it was tested for a first time during two short periods during winter at the Sammaltunturi site. In 2012, 2013 and 2015 both instruments were installed and used during PaCE (Doulgeris et al., 2020). In 2017 and 2019, only CAPS was used (Girdwood et al., 2020). An overview of each year's campaign duration and the cloud spectrometer ground setups' availability is presented in figure 2. Instruments that were used for measuring the meteorological variables and the solar radiation were operating continuously during all PaCE years. The instrumentation used during PaCE campaigns is described in detail in the following section. 


\subsection{Instrumentation}

In order to monitor meteorological variables, the station was equipped with an automatic weather station (Milos 500, Vaisala Inc.). A weather sensor (model FD12P, Vaisala Inc.) was used for measuring the horizontal visibility; the Vaisala HUMICAP was used for measuring the relative humidity; BAROCAP sensors were used for measuring the barometric pressure and PT100 sensors were used to measure temperature at $570 \mathrm{~m}$. Global radiation and photosynthetically active radiation were measured with a pyranometer and a photovoltaic detector, respectively. Additionally, the wind speed was measured with a heated cup and the wind direction with a heated wind vane. All the above meteorological variables were saved as one-minute averages. A detailed description of the weather sensors was given in Hatakka et al., (2003).

In order to conduct in-situ cloud ground-based measurements, we deployed two instruments. The cloud, aerosol and precipitation spectrometer (CAPS) and the forward-scattering spectrometer probe (FSSP-100), (Droplet Measurement Technologies (DMT); Boulder, CO, USA) (Fig. 3). The FSSP (model SPP-100, DMT) was originally manufactured by Particle Measuring Systems (PMS Inc., Boulder CO, USA). Both instruments were originally developed for airborne measurements but modified as ground setups by the manufacturer (DMT, USA). They were installed on the rooftop of the Sammaltunturi station. CAPS was fixed and heading always to the main wind direction of the station southwest, $\sim 225^{\circ}$, while the FSSP-100 was installed on a rotation platform to continuously face the wind. CAPS had a total height of $0.6 \mathrm{~m}$ on the roof where it was installed and a height of $4.5 \mathrm{~m}$ from the ground. FSSP had a total height of $0.6 \mathrm{~m}$ on the roof where it was installed and a height of $5.5 \mathrm{~m}$ from the ground. The two setups had a horizontal distance of $\sim 10 \mathrm{~m}$ and vertical distance of $\sim 1$ meter between them. From 2004 until 2012 a flow laminator was used inside the FSSP inlet (Lihavainen et al. 2008). However, the flow laminator was often blocked by supercooled cloud droplets at sub-zero temperatures and for this reason it was cleaned every hour if subcooled water was occurring. The laminator blockage was evident both during everyday instrument inspection and from the raw data. Only data cleaned of this artefact were used in the FSSP data set. However, without placing the laminator the Reynolds number indicates that the flow inside the inlet was still laminar. As a result, in 2012 we decided that the laminator would not be used in the FSSP setup anymore. Thus, the amount of data after 2012 were more extensive and the cases when the FSSP inlet was plugged were significantly less. A detailed description of both ground setups and the methodology we used for obtaining the ground-based cloud microphysical properties with in-situ method was documented in Doulgeris et al., 2020. Only a short overview is given here.

The CAPS has been widely used in airborne measurements for investigating the microphysical properties of clouds (e.g., Baumgardner, 2001; Baumgardner et al., 2011). The CAPS probe includes three instruments; the cloud and aerosol spectrometer (CAS) which measures smaller particles, the cloud imaging probe (CIP) and the hot -wire liquid water content ( $\mathrm{LWC}_{\mathrm{hw}}$ ) sensor. For the ground setup we deployed, the hot-wire LWC faced difficulties to operate in such extreme conditions; after operating in supercool liquid clouds (even for a short time) the sensor was accumulating ice. In addition, the lifetime of the sensor is limited and significantly smaller than the duration of the campaign. FSSP-100 was widely used for measuring droplet size distribution (Brenquier, 1989). CAS and FSSP-100 calculate the size of the particle from the intensity of the scattered light, using the Mie theory (Mie, 1908). Furthermore, backscatter optics measure light intensity in the 168 to $176^{\circ}$ range. This allows the determination of the real component of a particle's refractive index for spherical particles. The CIP is a single particle optical array probe. Its design is based on optical measurement techniques whereby single optical imaging passes through a collimated laser beam and is projected onto a linear array of 64 photodetectors. The count of the particle is dependent on a change in the light level of each diode.

All the instruments were calibrated before and after each campaign. Until 2011, we relied on the manufacturer calibration that was done at DMT. After 2011, we also started to perform calibration at the FMI on top of manufacturer calibration to ensure the quality of the produced data. For the calibration of the CAS and FSSP-100 glass beads in the diameter size range 2-40 $\mu \mathrm{m}$ and 
polystyrene latex sphere (PSL) standards in the diameter size range 0.74 - $2 \mu \mathrm{m}$ were used. To calibrate the CIP, a spinning glass disk with opaque dots of known size was used.

The CAPS ground setup included a high-flow pump (Baldor, Reliance, USA) which was working as an inhalation system. The inhalation system was made and provided by the manufacturer (DMT). A custom inhalation system with high flow ventilator was also made by the manufacturer (PMS) and employed through FSSP-100 inlet to make sure that we will maintain a constant flow through it. A digital thermo-anemometer (model 471, Dwyer Inc.) was used during each campaign for checking daily cloud spectrometers' air speed. The FSSP air speed inside the inlet was calculated from the measured airspeed in front of the inlet, except in 2004 and 2005 when the air speed was calculated with measured volume flow rate through the inlet. There, a necking inside the inlet led the flow from inner diameter $3.8 \mathrm{~cm}$ to $2.0 \mathrm{~cm}$. Both spectrometers were equipped with anti-ice systems as they were modified by the manufacturers (DMT for CAPS and PMS for FSSP-100) for ground-based use. Despite the existing anti-ice features, due to the subzero temperatures that they were facing, snow or ice could accumulate and affect the airspeed inside the probe inlets. For this reason, to ensure the proper operation of the instruments, they were inspected and cleaned twice per day, every morning and evening (approximately every 12 hours).

The ground-based in-situ cloud measurements provided the cloud and precipitation size distribution. On top, the PADS software that was used for the data acquisition of CAPS measurements (DMT Manual, 2011), derived the number concentration $\left(N_{c}\right.$, $\mathrm{cm}^{-3}$ ), liquid water content (LWC, $\mathrm{g} \mathrm{cm}^{-3}$ ), median volume diameter (MVD, $\left.\mu \mathrm{m}\right)$ and effective diameter, (ED, $\mu \mathrm{m}$ ). For the FSSP100, $N_{\mathrm{c}}$, LWC, MVD and ED were also derived using the same equations (Doulgeris et al., 2019), since we have used an older software for data acquisition (PACS 2.2, DMT).

An overview of the instrumentation and their operational characteristics we used for cloud measurements are e summarized in Table 1.

\section{Overview of data set and quality control description}

In the given data set, only measurements when the station was inside a cloud were used. Data from each cloud probe and the weather station were quality controlled and unified in a common format for any further analysis. The presence of a cloud at the station was identified with three different factors. First, we checked the droplet size distribution measured from both the cloud spectrometers. was the main parameter to consider that the station was inside a cloud. Then, to confirm this assumption, we crosschecked the droplets counts with two meteorological variables; the relative humidity at the measurement site which was expected to be $\sim 100 \%$ and the horizontal visibility which should be less than $1 \mathrm{~km}$, when the Sammaltunturi station is in the cloud. In case that one of the factors was not fulfilled, a final inspection was done visually using pictures recorded by an automatic weather camera installed on the roof of the station.

During PaCE 2004 and 2005 the sampling time of the FSSP-100 was 15 s. During Pace 2009 the instrument was set to

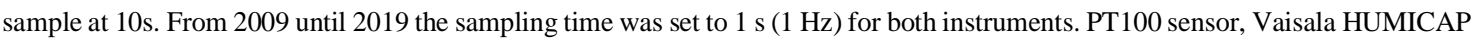
and BAROCAP sensors, the pyranometer, the heated cup and wind vane were also set to sample to $1 \mathrm{~s}$. FD12P Vaisala weather sensor sampling frequency was $15 \mathrm{~s}$. For every year, minute averages were calculated for each cloud spectrometer and each meteorological variable. As a result, we obtained the cloud droplet size distribution and several meteorological variables for each minute and as derived parameters the $N_{\mathrm{c}}\left(\mathrm{cm}^{-3}\right)$, LWC $\left(\mathrm{g} \mathrm{cm}^{-3}\right)$, MVD $(\mu \mathrm{m})$ and $\mathrm{ED}(\mu \mathrm{m})$. All data sets were converted to NetCDF format. All times in this work are given in UTC time. Our dataset includes a separate NetCDF and .cvs file for each cloud spectrometer and for each year under the file name PACE.yyyy.cloud_spectrometer.nc and PACE.yyyy.cloud_spectrometer.cvs. (example names). For every file, the sampling area $\left(\mathrm{mm}^{2}\right)$ and the probe air speed $\left(\mathrm{ms}^{-1}\right)$ that was used to derive each parameter is provided. In addition, it includes the cleaned timeline data set of the following cloud properties and meteorological variables: Year (YYYY), day (DD), month (MM), hour (HH), min (MN), size bin lower limit, size bin higher limit, number concentration $\left(\mathrm{cm}^{-3}\right)$, liquid water content $\left(\mathrm{g} \mathrm{cm}^{-3}\right)$, effective diameter $(\mu \mathrm{m})$, median volume diameter $(\mu \mathrm{m})$, the calculated $\mathrm{d} N / \mathrm{d} \log D \mathrm{p}\left(\mathrm{cm}^{-3}\right)$ values in 
each bin, temperature at 570 meters $\left({ }^{\circ} \mathrm{C}\right)$, dew point $\left({ }^{\circ} \mathrm{C}\right)$, humidity at 570 meters $(\%)$, pressure $(\mathrm{hPa})$, wind speed $\left(\mathrm{m} \mathrm{s}^{-1}\right)$, wind direction (degrees), global solar radiation $\left(\mathrm{Wm}^{-2}\right)$, photosynthetically active radiation $\left(\mu \mathrm{mol} \mathrm{m}^{-2} \mathrm{~s}^{-1}\right)$ and the horizontal visibility $(\mathrm{m})$. The derived cloud parameters (number concentration $\left(\mathrm{cm}^{-3}\right)$, liquid water content $\left(\mathrm{g} \mathrm{cm}^{-3}\right)$, effective diameter $(\mu \mathrm{m})$, median volume diameter $(\mu \mathrm{m})$ ) were not included in the CIP files. The number of cloud droplets per minute in CIP size range lead to statistically biased values and for this reason we decided to exclude them. The variables, naming abbreviations and units are summarized in Table 2.

The CAS contains 30 size bins with forward scattering upper bin size of $0.61,0.68,0.75,0.82,0.89,0.96,1.03,1.1,1.17$, $1.25,1.5,2,2.5,3,3.5,4,5,6.5,7.2,7.910 .2,12.5,15,20,25,30,35,40,45$ and $50 \mu \mathrm{m}$ and the CIP contains 62 size bins with bin size of $15,30,45,60,75,90,105,120,135,150,165,180,195,210,225,240,255,270,285,300,315,330,345,360,375,390$, $405,420,435,450,465,480,495,510,525,540,555,570,585,600,615,630,645,660,675,690,705,720,735,750,765,780$, $795,810,825,840,855,870,885,900,915$ and $930 \mu \mathrm{m}$. For the FSSP-100 two different bin size ranges were used. During 2004 and 2005 the instrument was set up to use 30 size bins with forward scattering upper bin size of 3.0, 4.5, 6.0, 7.5, 9.0, 10.5, 12.0, 13.5, 15.0, 16.5, 18.0, 19.5, 21.0, 22.5, 24.0, 25.5, 27, 28.5, 30.0, 31.5, 33.0, 34.5, 36.0, 37.5, 39.0, 40.5, 42.0, 43.5, 45.0, 47.0. From 2009 until 2015, the FSSP was set up to use 40 size bins with forward scattering upper bin size of 1.2, 2.4, 3.5, 4.7, 5.9, 7.1, 8.2, 9.4, 10.6, 11.8, 12.9, 14.1, 15.3, 16.5, 17.6, 18.8, 20, 21.2, 22.3, 23.5, 24.7, 25.9, 27, 28.2, 29.4, 30.6, 31.7, 32.9, 34.1, 35.3, $36.4,37.6,38.8,40,41.1,42.3,43.5,44.7,45.8$ and $47 \mu \mathrm{m}$.

Measurements of each year were inspected to ensure a good quality in this data set following the same steps. First, the raw data set was checked in order to eliminate and exclude from further analysis any case when each cloud probe was partially or fully blocked. Then, we used the suggested limitations (Doulgeris et al., 2020) for the data analysis of the CAS and FSSP-100 ground setups. There, it was pointed out that the CAPS (that was fixed to one direction) showed significant sampling losses when it was not facing the wind direction. For this reason, the data that were obtained in the wind iso-axial conditions were considered to have the best quality. Thus, regarding CAPS, only the measurements when the instrument was facing the wind direction were included. FSSP-100 ground setup was always directed against the wind direction and as a result we provided measurements from all wind sectors. Missing data points were marked as -9999.9.

As it is shown in Fig.4, the observation hours after PACE 2013 when the campaigns had longer duration are significantly more. The amount of data set in these years is unique and provides a significant source of information. An overview of meteorological variables is presented for each campaign during the FSSP-100 and CAPS ground setups were operative. In Fig. 5, a statistical description of the temperature at $570 \mathrm{MSL}$ for each campaign is illustrated. In Fig. 6, the percentage of the data set for each year that the Global solar radiation was more than 0 is shown to estimate the amount of data we had for each campaign during sunlight. Moreover, an overview of the microphysical derived cloud properties data from each campaign is presented. Thus, in Fig.7, Fig.8 and Fig.9, the number concentration, the effective diameter and the liquid water content are presented for each campaign and $\mathrm{f}$ the FSSP-100 and CAS ground setups respectively.

\section{Data availability}

Each described data set was collected by Finnish Meteorological Institute during PaCE campaigns and was published in the described form at FMI open data repository. All data sets have undergone thorough quality control and false readings were eliminated. Datasets can be all found here: https://doi.org/10.23728/FMI-B2SHARE.988739D21B824C709084E88ED6C6D54B

(Doulgeris et al.,2021).

\section{Code availability}


Software developed to process and display the data from the cloud ground base spectrometers are not publicly available and leverages licensed data analysis software (MATLAB). This software contains intellectual property that is not meant for public dissemination.

\section{Summary}

215 In this study we produced and summarized data sets obtained from two cloud ground base spectrometers (CAPS and FSSP-100 ground setups) owned by the FMI during eight years of PaCE campaigns conducted during autumns from 2004 until 2019 along with several meteorological variables. PaCE campaigns took place in the Finnish sub-arctic region in a clear environment in temperatures that were usually below zero. In section 2, we describe the measuring site where PaCE campaigns took place and the cloud ground spectrometers setups that were used to obtain the cloud data along with the instrumentation that was used to monitor the weather conditions. In Section 3 an overview of the presented data set is presented.

These observations gathered in sub-arctic conditions are a unique source of in situ cloud measurements, which can contribute to the understanding of the cloud dynamics and formation in a sub-arctic environment in different meteorological conditions. Such semi long observations are difficult to obtain in similar environments due to current lack of instrumentation. Each data set includes a combination of cloud microphysical properties (size distribution as a measured parameter and additionally as derived parameters the number concentration, effective diameter, median volume diameter and the liquid water content) along with several meteorological variables (temperature, dew point temperature, humidity, pressure, wind speed, wind direction, (global solar) sun radiation and visibility). Even though the data set includes measurements from eight campaigns, we would propose a case-bycase cloud investigation. Due to the inhomogeneity of the presented cloud cases, it is challenging to retrieve any trend that can be unambiguously connected to changes in the atmosphere. Also, the quality of data set may differ for each campaign due to the different amount of observations per year and our experience to operate the ground-based spectrometers through the years. In addition, each cloud case could be of different mass origin. We therefore strongly recommend avoiding any trend analysis based on the presented data set. However, this data set provides a helpful contribution to cloud microphysics processes on shorter timescales. Furthermore, it can be used as complementary in model development. 


\begin{tabular}{ll} 
Appendix A: Abbreviations & \\
PaCE & Pallas Cloud Experiment \\
GAW & Global Atmosphere Watch \\
UAS & Unmanned Aerial System \\
FMI & Finnish Meteorological Institute \\
CAPS & Cloud, aerosol and precipitation spectrometer \\
CAS & Cloud and aerosol spectrometer \\
CIP & Cloud imaging probe \\
LWC & Hot -wire liquid water content sensor \\
FSSP -100 & Forward-scattering spectrometer probe \\
DMT & Droplet Measurement Technologies \\
PMS & Particle Measuring Systems \\
PSL & Polystyrene latex sphere \\
$N_{\mathrm{c}}$ & Number concentration \\
LWC & Liquid water content \\
ED & Effective diameter \\
MVD & Median volume diameter \\
$T$ & Temperature at 570 MSL \\
$T_{\mathrm{DP}}$ & Dew point temperature \\
RH & Relative Humidity at 570 MSL \\
$P$ & Pressure \\
$W_{\mathrm{s}}$ & Wind speed \\
$W_{\text {dir }}$ & Wind direction \\
$S_{\text {rad }}$ & Global solar radiation \\
PAR & Photosynthetically active radiation \\
$V$ & \\
& Horizontal Visibility \\
\hline & \\
&
\end{tabular}

260 Author contributions. KD wrote the paper with contributions from all co-authors. HL planned and coordinated PaCE 2004, 2005, 2009. HL and DB planned and coordinated PaCE 2012 and 2013. KD and DB planned and coordinated PaCE15, 17 and 19. KD and DB processed, analyzed and quality controlled the data set. VMK and APH reviewed and edited the manuscript.

Competing interests. The authors declare no conflict of interest.

Acknowledgements: This work was supported by the Koneen Säätio (grant no. 46-6817), the NordForsk (grant no. 26060), the Academy of Finland (grant no. 269095), the Academy of Finland Center of Excellence program (grant no. 307331), Academy of Finland Flagship funding (grant no. 337552), the Natural Environment Research Council (NERC (grant no. NE-L011514-1)). This project has received funding from the European Union, Seventh Framework Programme (BACCHUS) (grant no. 603445)) and 
H2020 research and innovation program (ACTRIS-2, the European Research Infrastructure for the observation of Aerosol, Clouds, and Trace gases) (grant agreement no. 654109).

\section{References}

Albrecht, B. A.: Aerosols, cloud microphysics, and fractional cloudiness, Science, 245, 1227-1230, 1989.

Asmi, E., Kivekäs, N., Kerminen, V.-M., Komppula, M., Hyvärinen, A.-P., Hatakka, J., Viisanen, Y., and Lihavainen, H.: Secondary new particle formation in Northern Finland Pallas site between the years 2000 and 2010, Atmos. Chem. Phys., 11, 12959-12972, https://doi.org/10.5194/acp-11-12959-2011, 2011.

280 Backman, J., Schmeisser, L., Virkkula, A., Ogren, J. A., Asmi, E., Starkweather, S., Sharma, S., Eleftheriadis, K., Uttal, T., Jefferson, A., Bergin, M., Makshtas, A., Tunved, P., and Fiebig, M.: On Aethalometer measurement uncertainties and an instrument correction factor for the Arctic, Atmos. Meas. Tech., 10, 5039-5062, https://doi.org/10.5194/amt-10-5039-2017, 2017.

Baumgardner, D.: Status of in-situ microphysical measurements. Proc. ETL/CSU Cloud Modeling and Measurement

Workshop, Boulder, CO, NOAA/ETL, 67-102.1996.

Baumgardner, D., Jonsson, H., Dawson, W., O'Connor D., and Newton R.: The cloud, aerosol and precipitation spectrometer (CAPS): A new instrument for cloud investigations, Atmos. Res., 59-60, 251-2-64, https://doi.org/10.1016/S0169-8095(01)00119$3,2001$.

Baumgardner, D., Brenguier, J., Bucholtz, A., Coe, H., DeMott, P., Garrett, T., Gayet, J., Hermann, M., Heymsfield, A., Korolev, A., Kramer, M., Petzold, A., Strapp, W., Pilewskie, P., Taylor, J., Twohy, C., Wendisch, M., Bachalo, W., and Chuang, P.: Airborne instruments to measure atmospheric aerosol particles, clouds and radiation: A cook's tour of mature and emerging technology, Atmos. Res., 102, 10-29, https://doi.org/10.1016/j.atmosres.2011.06.021, 2011.

Baumgardner, D., Abel, S. J., Axisa, D., Cotton, R., Crosier, J., Field, P., Gurganus, C., Heymsfield, A., Korolev, A., Krämer, M., Lawson, P., McFarquhar, G., Ulanowski, Z., and Um, J.: Cloud Ice Properties: In Situ Measurement Challenges, Meteor. Mon., 58, 9.1-9.23, https://doi.org/10.1175/AMSMONOGRAPHS-D16-0011.1, 2017.

300 Boucher, O., Randall, D., Artaxo, P., Bretherton, C., Feingold, G., Forster, P., Kerminen, V.-M., Kondo, Y., Liao, H., Lohmann, U., Rasch, P., Satheesh, S. K., Sherwood, S., Stevens, B., and Zhang, X. Y.: Clouds and aerosols, in: Climate Change 2013: The Physical Science Basis. Contribution of Working Group I to the Fifth Assessment Report of the Intergovernmental Panel on Climate Change, edited by: Stocker, T. F., Qin, D., Plattner, G.-K., Tignor, M., Allen, S. K., Doschung, J., Nauels, A., Xia, Y., Bex, V., and Midgley, P. M., Cambridge University Press, 571-657, https://doi.org/10.1017/CBO9781107415324.016, 2013.

Bony, S., Stevens, B., Frierson, D., Jakob, C., Kageyama, M., Pincus, R., Shepherd, T. G., Sherwood, S. C., Siebesma, A. P., Sobel, A. H., Watanabe, M. and Webb, M. J.: Clouds, circulation and climate sensitivity. Nature Geosci 8, 261-268, https://doi.org/10.1038/ngeo2398, 2015

310 Brenguier, J. L.: Coincidence and Dead-Time Corrections for Particles Counters. Part II: High Concentration Measurements with an FSSP, J. Atmos. Ocean. Tech., 6, 585-598, https://doi.org/10.1175/1520-0426(1989)006<0585:CADTCF>2.0.CO;2, 1989.

Brus, D., Gustafsson, J., Vakkari, V., Kemppinen, O., de Boer, G. and Hirsikko, A.: Measurement report: Properties of aerosol and gases in the vertical profile during the LAPSE-RATE campaign, Atmos. Chem. Phys., 21(1), 517-533, https://doi.org/10.5194/acp21-517-2021, 2021.

Chang, Y., Guo, X., Tang, J. and Lu, G.:Aircraft measurement campaign on summer cloud microphysical properties over the Tibetan Plateau. Sci Rep 9, 4912, https://doi.org/10.1038/s41598-019-41514-5,2019.

320 Craig, L., Moharreri, A., Rogers, D. C., Anderson, B., and Dhaniyala, S.: Aircraft-Based Aerosol Sampling in Clouds: Performance Characterization of Flow-Restriction Aerosol Inlets, J. Atmos. Ocean. Tech., 31, 2512-2521, https://doi.org/10.1175/JTECH-D-14$00022.1,2014$.

Devenish, B.J., Bartello P., Brenguier J.-L., Collins L.R., Grabowski W.W., Jzermans R.H.A., Malinowski S.P., Reeks M.W.,

325 Vassilicos J.C., Wang L-P, Warhaft Z.: Droplet growth in warm turbulent clouds. Q. J. R. Meteorol. Soc. 138: 1401-1429. DOI:10.1002/qj.1897,2012. 
330 Doulgeris, K. M., Brus, D., Raatikainen, T., and Kerminen V.-M.: A Finnish Meteorological Institute-Aerosol Cloud Interaction Tube (FMI-ACIT): Experimental setup and tests of proper operation, The Journal of Chemical Physics, 149, 124201. doi:10.1063/1.5037298, 2018.

Doulgeris, K.-M., Komppula, M., Romakkaniemi, S., Hyvärinen, A.-P., Kerminen, V.-M., and Brus, D.: In situ cloud ground-based 335 measurements in the Finnish sub-Arctic: intercomparison of three cloud spectrometer setups, Atmos. Meas. Tech., 13, 5129-5147, https://doi.org/10.5194/amt-13-5129-2020, 2020.

Doulgeris, K.-M., Lihavainen, H., Hyvärinen, A.-P., Kerminen, V.-M., and Brus, D.: Data set for Doulgeris et al.2021: In-situ microphysical characterization of low-level clouds in the Finnish sub-Arctic, extensive dataset. [Data set]. Finnish Meteorological Institute. https://doi.org/10.23728/FMI-B2SHARE.988739D21B824C709084E88ED6C6D54B, 2021.

Febvre, G., Gayet, J.-F., Shcherbakov, V., Gourbeyre, C., and Jourdan, O.: Some effects of ice crystals on the FSSP measurements in mixed phase clouds, Atmos. Chem. Phys., 12, 8963-8977, https://doi.org/10.5194/acp-12-8963-2012, 2012.

345 Guichard F. and Couvreux F.: A short review of numerical cloud-resolving models, Tellus A: Dynamic Meteorology and Oceanography, 69:1, DOI: 10.1080/16000870.2017.1373578, 2017.

Girdwood, J., Smith, H., Stanley, W., Ulanowski, Z., Stopford, C., Chemel, C., Doulgeris, K.-M., Brus, D., Campbell, D., and Mackenzie, R.: Design and field campaign validation of a multi-rotor unmanned aerial vehicle and optical particle counter, Atmos. Meas. Tech., 13, 6613-6630, https://doi.org/10.5194/amt-13-6613-2020, 2020.

350 Grabowski, W. W., Morrison H., Shima S., Abade G. C., Dziekan P., and Pawlowska H.: Modeling of Cloud Microphysics: Can We Do Better? Bull. Amer. Meteor. Soc., 100, 655-672, https://doi.org/10.1175/BAMS-D-18-0005.1, 2019.

Guyot, G., Gourbeyre, C., Febvre, G., Shcherbakov, V., Burnet, F., Dupont, J.-C., Sellegri, K., and Jourdan, O.: Quantitative evaluation of seven optical sensors for cloud microphysical measurements at the Puy-de-Dôme Observatory, France, Atmos. Meas.

355 Tech., 8, 4347-4367, https://doi.org/10.5194/amt-8-4347-2015, 2015.

Harrison R. G., K. A. Nicoll, D. J. Tilley, G. J. Marlton, S. Chindea, G. P. Dingley, P. Iravani, D. J. Cleaver, J. L. du Bois, and D. Brus: Demonstration of a remotely-piloted atmospheric measurement and charge release platform for geoengineering, J. Atmos. Ocean. Technol, 38(1), 63-75, https://doi.org/10.1175/JTECH-D-20-0092.1, 2021.

Hatakka, J., Aalto, T., Aaltonen, V., Aurela, M., Hakola, H., Komppula, M., Laurila, T., Lihavainen, H., Paatero, J., Salminen, K., and Viisanen Y., Overview of the atmospheric research activities and results at Pallas GAW station, Boreal Environ. Res., 8, 365$384,2003$.

365 Heymsfield, A., Thompsom, G., Morrison, H., Bansemer, A., Rasmussen, R. M., Minnis, P., Wang, Z. and Zhang,D.: Formation and Spread of Aircraft- Induced Holes in Clouds, Science, 33, 77-81, doi: 10.1126/science.1202851, 2011.

Komppula, M., Lihavainen, H., Kerminen, V.-M., Kulmala, M., and Viisanen, Y.: Measurements of cloud droplet activation of aerosol particles at a clean subarctic background site, J. Geophys. Res., 110, D06204, https://doi.org/10.1029/2004JD005200, 2005.

Lance, S.: Coincidence Errors in a Cloud Droplet Probe (CDP) and a Cloud and Aerosol Spectrometer (CAS), and the Improved Performance of a Modified CDP, https://doi.org/10.1175/JTECH-D11-00208.1, 2012.

Lihavainen, H., Kerminen, V.-M., Komppula, M., Hyvärinen, A.-P., Laakia, J., Saarikoski, S., Makkonen, U., Kivekäs, N., Hillamo,

375 R., Kulmala, M., and Viisanen, Y.: Measurements of the relation between aerosol properties and microphysics and chemistry of low-level liquid water clouds in Northern Finland, Atmos. Chem. Phys., 8, 6925-6938, https://doi.org/10.5194/acp-8-6925-2008, 2008.

Lloyd, G., Choularton, T. W., Bower, K. N., Gallagher, M. W., Connolly, P. J., Flynn, M., Farrington, R., Crosier, J., Schlenczek, 380 O., Fugal, J., and Henneberger, J.: The origins of ice crystals measured in mixed-phase clouds at the high-alpine site Jungfraujoch, Atmos. Chem. Phys., 15, 12953-12969, https://doi.org/10.5194/acp-15-12953-2015, 2015.

Lohila A., Penttilä T., Jortikka S., Aalto T., Anttila P., Asmi E., Aurela M., Hatakka J., Hellén H., Henttonen H., Hänninen P., Kilkki J., Kyllönen K., Laurila T., Lepistö A., Lihavainen H., Makkonen U., Paatero J., Rask M., Sutinen R., Tuovinen J.-P.,

385 Vuorenmaa J. and Viisanen Y.: Preface to the special issue on integrated research of atmosphere, ecosystems and environment at Pallas. Boreal Env. Res. 20: 431-454, 2015. 
Lowenthal, D. H., Hallar, A. G., David, R. O., McCubbin, I. B., Borys, R. D., and Mace, G. G.: Mixed-phase orographic cloud microphysics during StormVEx and IFRACS, Atmos. Chem. Phys., 19, 5387-5401, https://doi.org/10.5194/acp-19-5387-2019, 2019.

McFarquhar, G. M., Bretherton, C., Marchand, R., Protat, A., DeMott, P. J., Alexander, S. P., Roberts, G. C., Twohy, C. H., Toohey, D., Siems, S., Huang, Y., Wood, R., Rauber, R. M., Lasher-Trapp, S., Jensen, J., Stith, J., Mace, J., Um, J., Järvinen, E., Schnaiter, M., Gettelman, A., Sanchez, K. J., McCluskey, C. S., Russell, L. M., McCoy, I. L., Atlas, R., Bardeen, C. G., Moore, K. A., Hill, 395 T. C. J., Humphries, R. S., Keywood, M. D., Ristovski, Z., Cravigan, L., Schofield, R., Fairall, C., Mallet, M. D., Kreidenweis, S. M., Rainwater, B., D’Alessandro, J., Wang, Y., Wu, W., Saliba, G., Levin, E. J. T., Ding, S., Lang, F., Truong, S. C., Wolff, C., Haggerty, J., Harvey, M. J., Klekociuk, A., and McDonald, A.: Observations of clouds, aerosols, precipitation, and surface radiation over the Southern Ocean: An overview of CAPRICORN, MARCUS, MICRE and SOCRATES, B. Am. Meteorol. Soc., 1-92, https://doi.org/10.1175/BAMS-D-20- 0132.1, 2020

400

Mie, G.: Beiträge zur Optik trüber Medien, speziell kolloidaler Metallösungen, Ann. Phys.-Berlin, 330, 377-445, 1908.

Droplet Measurement Technologies Manual: CAPS operator manual, DOC-0066 Revision F, DMT, Boulder, Colorado, USA, 2011.

Möhler, O., Stetzer, O., Schaefers, S., Linke, C., Schnaiter, M., Tiede, R., Saathoff, H., Krämer, M., Mangold, A., Budz, P., Zink,

405 P., Schreiner, J., Mauersberger, K., Haag, W., Kärcher, B., and Schurath, U.: Experimental investigation of homogeneous freezing of sulphuric acid particles in the aerosol chamber AIDA, Atmos. Chem. Phys., 3, 211-223, https://doi.org/10.5194/acp-3-211-2003, 2003.

Morrison, A. L., Kay, J. E., Frey, W. R., Chepfer, H. , and Guzman, R.: Cloud response to Arctic sea ice loss and implications for 410 future feedback in the CESM1 climate model. J. Geophys. Res. Atmos., 124, 1003-1020, https://doi.org/10.1029/2018jd029142, 2019.

Nichman, L., Järvinen, E., Dorsey, J., Connolly, P., Duplissy, J., Fuchs, C., Ignatius, K., Sengupta, K., Stratmann, F., Möhler, O., Schnaiter, M., and Gallagher, M.: Intercomparison study and optical asphericity measurements of small ice particles in the CERN

415 CLOUD experiment, Atmos. Meas. Tech., 10, 3231-3248, https://doi.org/10.5194/amt-10-3231-2017, 2017.

Petäjä, T., O’Connor, E.J, Moisseev, D., Sinclair, V.A., Manninen, A.J., Väänänen, R., Von Lerber, A., Thornton, J.A., Nicoll, K., Petersen, W., Chandrasekar, V., Smith, J.N., Winkler, P.M., Krüger, O., Hakola, H., Timonen, H., Brus, D., Laurila, T., Asmi, E., Riekkola, M.-L., Mona, L., Massoli, P., Engelmann, R., Komppula, M., Wang, J., Kuang, C., Bäck, J., Virtanen, A., Levula, J.,

420 Ritsche, M., and Hickmon, N.: BAECC: A Field Campaign to Elucidate the Impact of Biogenic Aerosols on Clouds and Climate. B. Am. Meteorol. Soc., 97, 1909-1928, https://doi.org/10.1175/BAMS-D-14-00199.1, 2016.

Pruppacher, H. and Klett, J.: Microphysics of Clouds and Precipitation, Springer, Dordrecht, Netherlands, https://doi.org/10.1007/978-0-306-48100-0, 2010.

Rosenfeld, D. and Ulbrich, C. W.: Cloud Microphysical Properties, Processes, and Rainfall Estimation Opportunities, Meteor. Mon., 30, 237-237, https://doi.org/10.1175/0065-9401(2003)030<0237:CMPPAR>2.0.CO;2, 2003.

Stratmann, F., Kiselev, A., Wurzler, S., Wendisch, M., Heitzenberg, J., Charlson, R.J., Diehl, K., Wex, H. and, Schmidt, S.: 430 Laboratory Studies and Numerical Simulations of Cloud Droplet Formation under Realistic Supersaturation Conditions. J. Atmos. Oceanic Technol., 21, 876-887, https://doi.org/10.1175/1520-0426(2004)021<0876:LSANSO>2.0.CO;2, 2004.

Wandinger, U., Apituley, A., Blumenstock, T., Bukowiecki, N., Cammas, J.-P., Connolly, P., De Mazière, M., Dils, B., Fiebig, M., Freney, E., Gallagher, M., Godin-Beekmann, S., Goloub, P., Gysel, M., Haeffelin, M., Hase, F., Hermann, M., Herrmann, H., Jokinen, T., Komppula, M., Kubistin, D., Langerock, B., Lihavainen, H., Mihalopoulos, N., Laj, P., Lund Myhre, C., Mahieu, E.,

435 Mertes, S., Möhler, O., Mona, L., Nicolae, D., O'Connor, E., Palm, M., Pappalardo, G., Pazmino, A., Petäjä, T., Philippin, S., PlassDuelmer, C., Pospichal, B., Putaud, J.-P., Reimann, S., Rohrer, F., Russchenberg, H., Sauvage, S., Sellegri, K., Steinbrecher, R., Stratmann, F., Sussmann, R., Van Pinxteren, D., Van Roozendael M., Vigouroux C., Walden C., Wegene R., and Wiedensohler, A.: ACTRIS-PPP Deliverable D5.1: Documentation on technical concepts and requirements for ACTRIS Observational Platforms, available at: https://www.actris.eu/Portals/46/Documentation/ACTRIS PPP/Deliverables/Public/WP5_D5.1_M18.pdf?ver= 2018-

440 06-28-125343-273 (last access: 21 September 2020), 2018.

Wendisch, M., Macke, A., Ehrlich, A., Lüpkes, C., Mech, M., Chechin, D., Dethloff, K., Velasco, C. B., Bozem, H., Brückner, M., Clemen, H.-C., Crewell, S., Donth, T., Dupuy, R., Ebell, K., Egerer, U., Engelmann, R., Engler, C., Eppers, O., Gehrmann, M., Gong, X., Gottschalk, M., Gourbeyre, C., Griesche, H., Hartmann, J., Hartmann, M., Heinold, B., Herber, A., Herrmann, H., Heygster, G., Hoor, P., Jafariserajehlou, S., Jäkel, E., Järvinen, E., Jourdan, O., Kästner, U., Kecorius, S., Knudsen, E. M.,

445 Köllner, F., Kretzschmar, J., Lelli, L., Leroy, D., Maturilli, M., Mei, L., Mertes, S., Mioche, G., Neuber, R., Nicolaus, M., Nomokonova, T., Notholt, J., Palm, M., van Pinxteren, M., Quaas, J., Richter, P., Ruiz-Donoso, E., Schäfer, M., Schmieder, K., Schnaiter, M., Schneider, J., Schwarzenböck, A., Seifert, P., Shupe, M. D., Siebert, H., Spreen, G., Stapf, J., Stratmann, F., Vogl, T., Welti, A., Wex, H., Wiedensohler, A., Zanatta, M., and Zeppenfeld, S.: The Arctic Cloud Puzzle: Using 
https://doi.org/10.5194/essd-2021-297

Preprint. Discussion started: 13 September 2021

(c) Author(s) 2021. CC BY 4.0 License.

(c) (1)

ACLOUD/PASCAL Multiplatform Observations to Unravel the Role of Clouds and Aerosol Particles in Arctic Amplification, B. 450 Am. Meteorol. Soc., 100, 841-871, https://doi.org/10.1175/BAMS-D-18-0072.1, 2019.

455

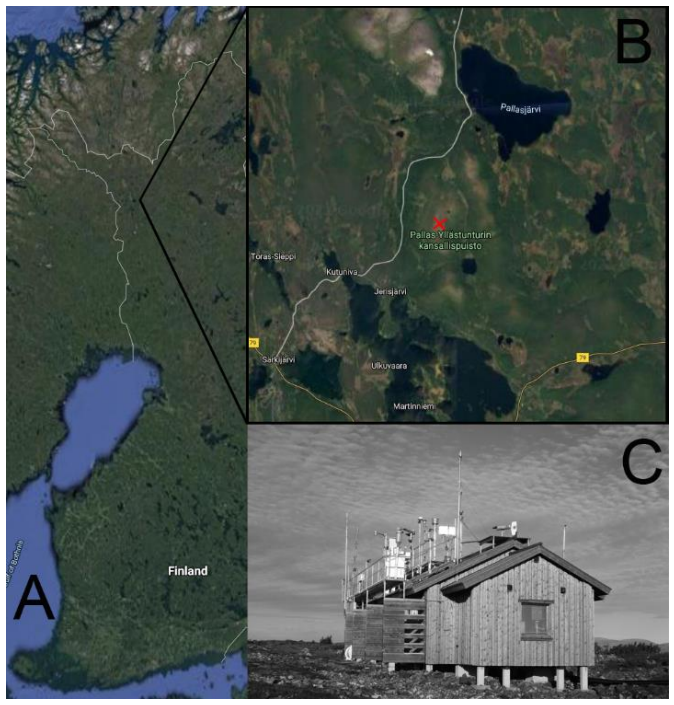

Figure 1. (a) Map of Finland showing the location of the measuring station, and (b) map of the wider Pallas area showing the Sammaltunturi measuring station (red cross). ( ) Google Maps (c) The Sammaltunturi measuring station during PaCE.

460

465 


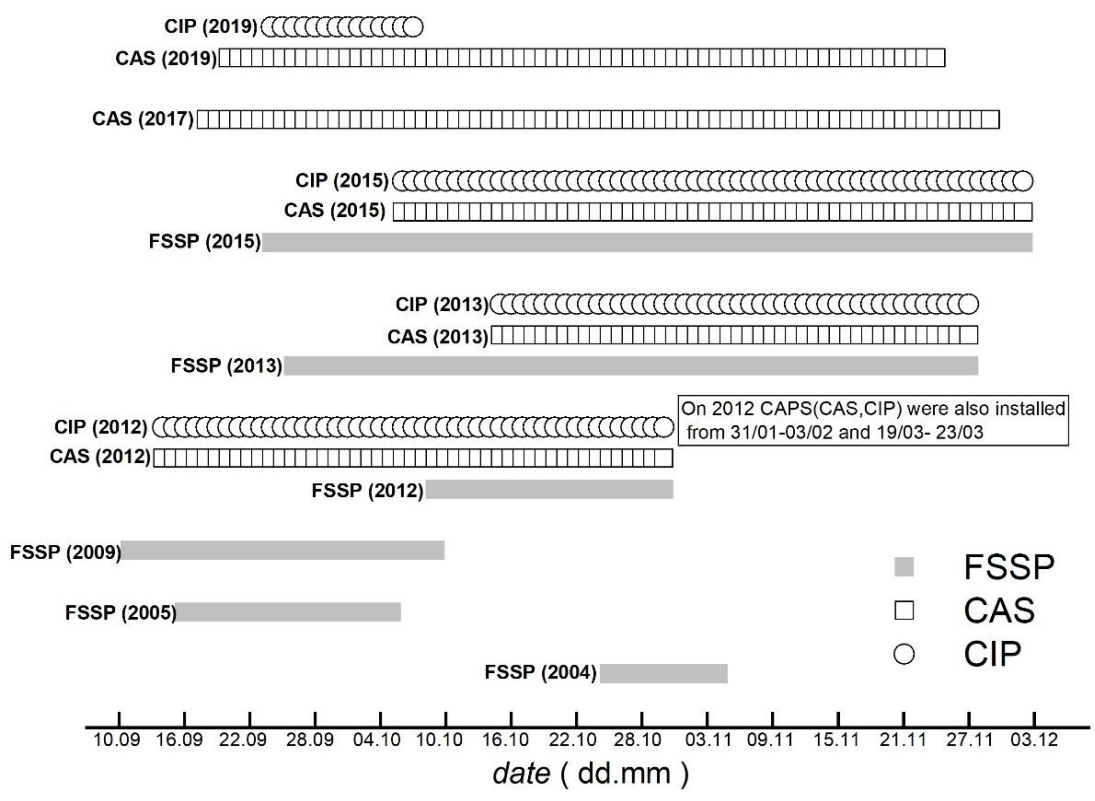

Figure 2. Cloud spectrometer ground setups' availability during $\mathrm{PaCE}$ is presented for each year. 
Table 1: An overview of instrumentation and their operational characteristics provided by manufacturer.

\begin{tabular}{|c|c|c|c|c|c|c|}
\hline Instrument & Operating range & $\begin{array}{c}\text { Number of } \\
\text { bins }\end{array}$ & $\begin{array}{l}\text { Sampling } \\
\text { frequency }\end{array}$ & $\begin{array}{l}\text { Air speed } \\
\text { range }\end{array}$ & Accuracy & Uncertainties \\
\hline \multicolumn{7}{|l|}{ Cloud instruments } \\
\hline$C A S, D M T$ & $0.51 \mu \mathrm{m}$ to $50 \mu \mathrm{m}$ & $\begin{array}{l}10,20,30 \text {, } \\
\text { or } 40\end{array}$ & 0.05 to $40 \mathrm{~Hz}$ & $10-200 \mathrm{~ms}^{-1}$ & $\begin{array}{l}\text { upper } N_{\mathrm{c}}>1,000 \\
\mathrm{~cm}^{-3} \text { after } \\
\text { corrections for } \\
\text { coincidence that } \\
\text { are about } 25 \% \text { at } \\
800 \text { and } 30 \% \text { at } \\
1,000 \text { particles } / \mathrm{cm}^{3} \\
\text { Sizing accuracy: } \\
20 \%\end{array}$ & $\begin{array}{l}\text { ambient } N_{\mathrm{c}} \text { of } 500 \\
\mathrm{~cm}^{-3}: 27 \% \\
\text { undercounting and } \\
20 \%-30 \% \\
\text { oversizing bias } \\
\text { Lance et al. (2012) } \\
L W C: 40 \% \\
\text { (DMT Manual) }\end{array}$ \\
\hline$C I P, \mathrm{DMT}$ & $12.5 \mu \mathrm{m}$ to $1.55 \mathrm{~mm}$ & 62 & 0.05 to $40 \mathrm{~Hz}$ & $10-300 \mathrm{~ms}^{-1}$ & $\begin{array}{l}\text { upper } N_{\mathrm{c}} \text { range up } \\
\text { to } 500 \text { particles/ } \\
\mathrm{cm}^{3} \text { for a CIP with } \\
\text { standard tips and } \\
\text { arm width } \\
\text { sizing accuracy: } \\
1 \mu \mathrm{m}\end{array}$ & $\begin{array}{l}\text { digitization } \\
\text { uncertainty of } \\
\text { approximately } 61 \\
\text { size resolution that } \\
\text { depends upon } \\
\text { where the particle } \\
\text { passes across the } \\
\text { array } \\
\text { Baumgardner et } \\
\text { al. (2017) }\end{array}$ \\
\hline FSSP-100, PMS & $0.5 \mu \mathrm{m}$ to $47 \mu \mathrm{m}$ & 15,30 or 40 & 0.05 to $40 \mathrm{~Hz}$ & & $\begin{array}{l}N_{\mathrm{c}} \text { accuracy: } 16 \% \\
\text { sizing accuracy: } \pm 3 \\
\mu \mathrm{m} \\
L W C \text { accuracy: } \\
30 \%-50 \% \\
\text { Baumgardner } \\
(1996)\end{array}$ & $\begin{array}{l}\text { derived } E D: 3 \mu \mathrm{m} \\
\text { derived } L W C: 30 \% \\
\text { Febvre et al. (2012) }\end{array}$ \\
\hline \multicolumn{7}{|c|}{ Meteorological instruments } \\
\hline & Range & \multicolumn{2}{|c|}{ Resolution } & \multirow[t]{2}{*}{ Sensitivit } & \multicolumn{2}{|r|}{ Accuracy } \\
\hline $\begin{array}{l}\text { PT100 sensor, } \\
\text { Vaisala }\end{array}$ & $-70-+180\left({ }^{\circ} \mathrm{C}\right)$ & \multicolumn{2}{|r|}{$\begin{array}{l}0.01 \\
\left({ }^{\circ} \mathrm{C}\right)\end{array}$} & & \multicolumn{2}{|r|}{$\begin{array}{l} \pm 0.1 \\
\left({ }^{\circ} \mathrm{C}\right)\end{array}$} \\
\hline $\begin{array}{l}\text { HUMICAP sensor, } \\
\text { Vaisala }\end{array}$ & $\begin{array}{l}0-100 \\
(\%) \mathrm{RH}\end{array}$ & \multicolumn{2}{|r|}{$\begin{array}{l}<0.01 \\
(\%) \mathrm{RH}\end{array}$} & \multicolumn{3}{|r|}{$\begin{array}{l} \pm 0.8 \\
(\%) \mathrm{RH}\end{array}$} \\
\hline $\begin{array}{l}\text { BAROCAP sensor, } \\
\text { Vaisala }\end{array}$ & $500-1000(\mathrm{hPa})$ & \multicolumn{2}{|r|}{$\begin{array}{c}0.01 \\
(\mathrm{hPa})\end{array}$} & \multicolumn{3}{|r|}{$\begin{array}{l} \pm 0.15 \\
(\mathrm{hPa})\end{array}$} \\
\hline $\begin{array}{l}\text { heated cup and } \\
\text { wind vane, } \\
\text { Vaisala }\end{array}$ & $\begin{array}{c}0.4-75\left(\mathrm{~ms}^{-1}\right) \\
0-360^{\circ}\end{array}$ & \multicolumn{2}{|r|}{$\begin{array}{c}0.1 \\
\left(\mathrm{~ms}^{-1}\right) \\
1^{\circ}\end{array}$} & \multicolumn{3}{|r|}{$\begin{array}{c} \pm 0.17 \\
\left(\mathrm{~ms}^{-1}\right) \\
\pm 3^{\circ}\end{array}$} \\
\hline $\begin{array}{l}\text { Pyranometer, } \\
\text { Vaisala }\end{array}$ & $305-2000\left(\mathrm{Wm}^{-1}\right)$ & & & \multirow[t]{2}{*}{$\begin{array}{r}9-15 \\
(\mu \mathrm{V} \mathrm{Wm}\end{array}$} & \multicolumn{2}{|c|}{$\begin{array}{c}< \pm 20 \mathrm{Wm}^{-2} \text { at } 1000 \\
\mathrm{Wm}^{-2}\end{array}$} \\
\hline $\begin{array}{l}F D 12 P, \\
\text { Vaisala }\end{array}$ & $\begin{array}{c}10-50000 \\
(\mathrm{~m})\end{array}$ & & & & \multicolumn{2}{|c|}{$\begin{array}{c} \\
\pm 10 \%, 10-10000 \mathrm{~m} \\
\pm 20 \%, 10000-50000 \mathrm{~m}\end{array}$} \\
\hline
\end{tabular}




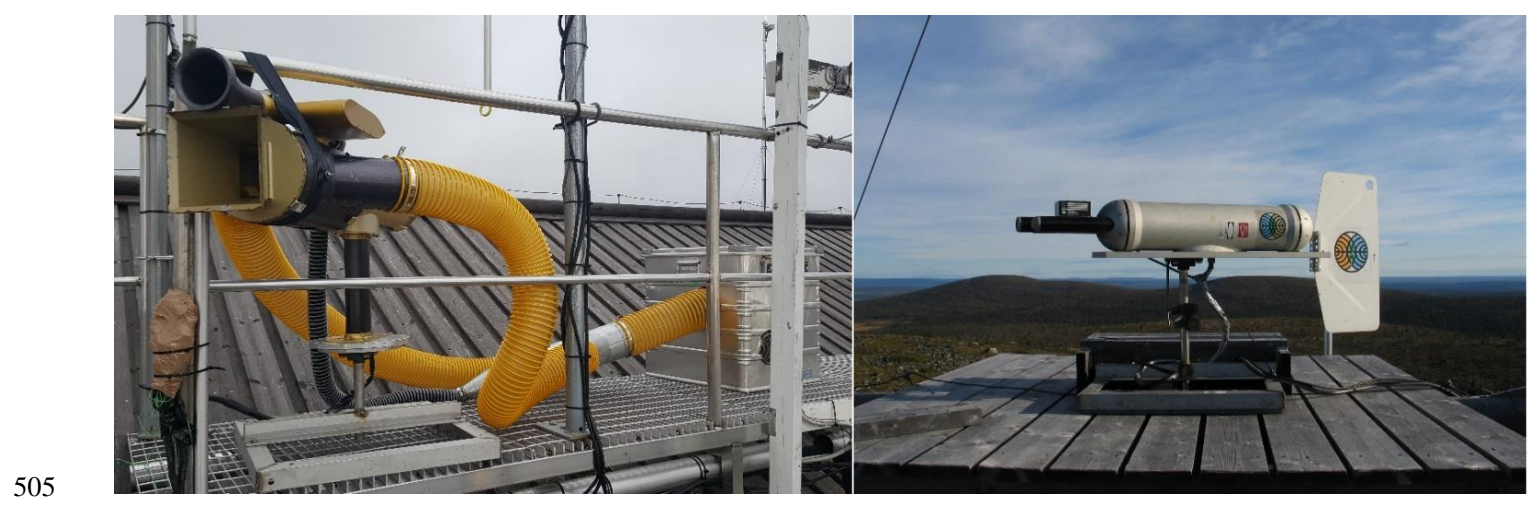

Figure 3. CAPS (left) and FSSP-100 (right) ground setups as installed on the roof of Sammaltunturi station. 
https://doi.org/10.5194/essd-2021-297

Preprint. Discussion started: 13 September 2021

(c) Author(s) 2021. CC BY 4.0 License.

Table 2: Cloud properties and meteorological variables along with abbreviations and units as they are included in each data set.

\begin{tabular}{|c|c|c|c|}
\hline Variable name & Abbreviations & Units & Comments \\
\hline \multicolumn{4}{|l|}{ Cloud properties } \\
\hline Number concentration & $N_{\mathrm{c}}$ & $\mathrm{cm}^{-3}$ & derived parameter \\
\hline Liquid water content & LWC & $\mathrm{g} \mathrm{cm}^{-3}$ & derived parameter \\
\hline Effective diameter & ED & $\mu \mathrm{m}$ & derived parameter \\
\hline Median volume diameter & MVD & $\mu \mathrm{m}$ & derived parameter \\
\hline Size distribution & $\mathrm{d} N / \mathrm{d} \log D \mathrm{p}$ & $\mathrm{cm}^{-3} \mu \mathrm{m}^{-1}$ & $\begin{array}{c}\text { calculated from min } \\
\text { averages counts per bin }\end{array}$ \\
\hline \multicolumn{4}{|l|}{ Meteorological variables } \\
\hline Temperature at $570 \mathrm{~m}$ & $T$ & ${ }^{\circ} \mathrm{C}$ & PT100 sensor \\
\hline Dew point temperature & $T_{\mathrm{DP}}$ & ${ }^{\circ} \mathrm{C}$ & \\
\hline Relative Humidity at $570 \mathrm{~m}$ & $\mathrm{RH}$ & $\%$ & Vaisala HUMICAP sensor \\
\hline Pressure & $P$ & $\mathrm{hPa}$ & Vaisala BAROCAP sensor \\
\hline Wind speed & $W_{\mathrm{s}}$ & $\mathrm{ms}^{-1}$ & measured with a heated cup \\
\hline Wind direction & $W_{\text {dir }}$ & degrees & $\begin{array}{l}\text { measured with a heated } \\
\text { wind vane }\end{array}$ \\
\hline Global solar radiation & $S_{\mathrm{rad}}$ & $\mathrm{Wm}^{-2}$ & Pyranometer \\
\hline Photosynthetically active radiation & PAR & $\mu \mathrm{mol} \mathrm{m}{ }^{-2} \mathrm{~s}^{-1}$ & Photovoltaic detector \\
\hline Horizontal Visibility & $V$ & $\mathrm{~m}$ & $\begin{array}{l}\text { FD12P Vaisala weather } \\
\text { station }\end{array}$ \\
\hline
\end{tabular}




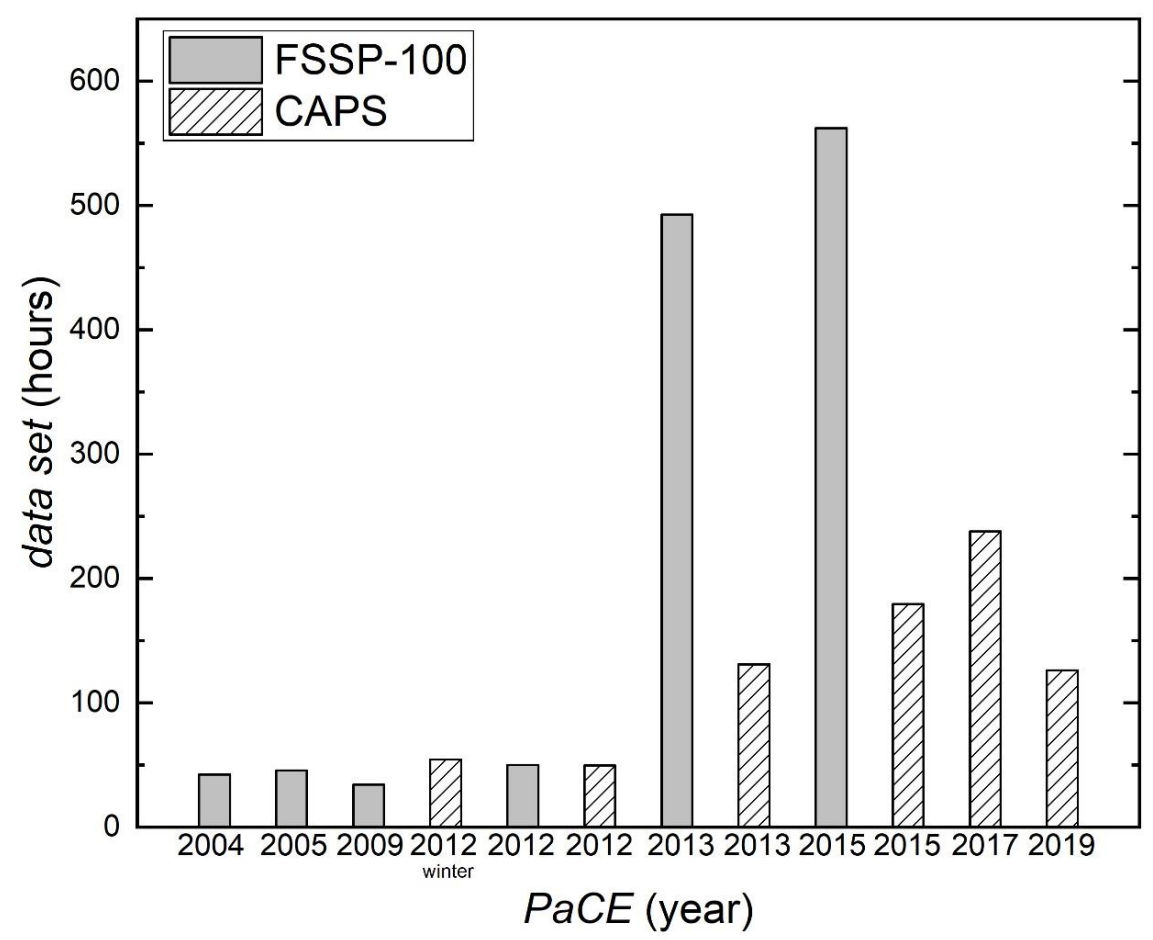

Figure 4. Hours of observation data collected for each PaCE campaign when the FSSP-100 and CAPS ground setups were operative. 


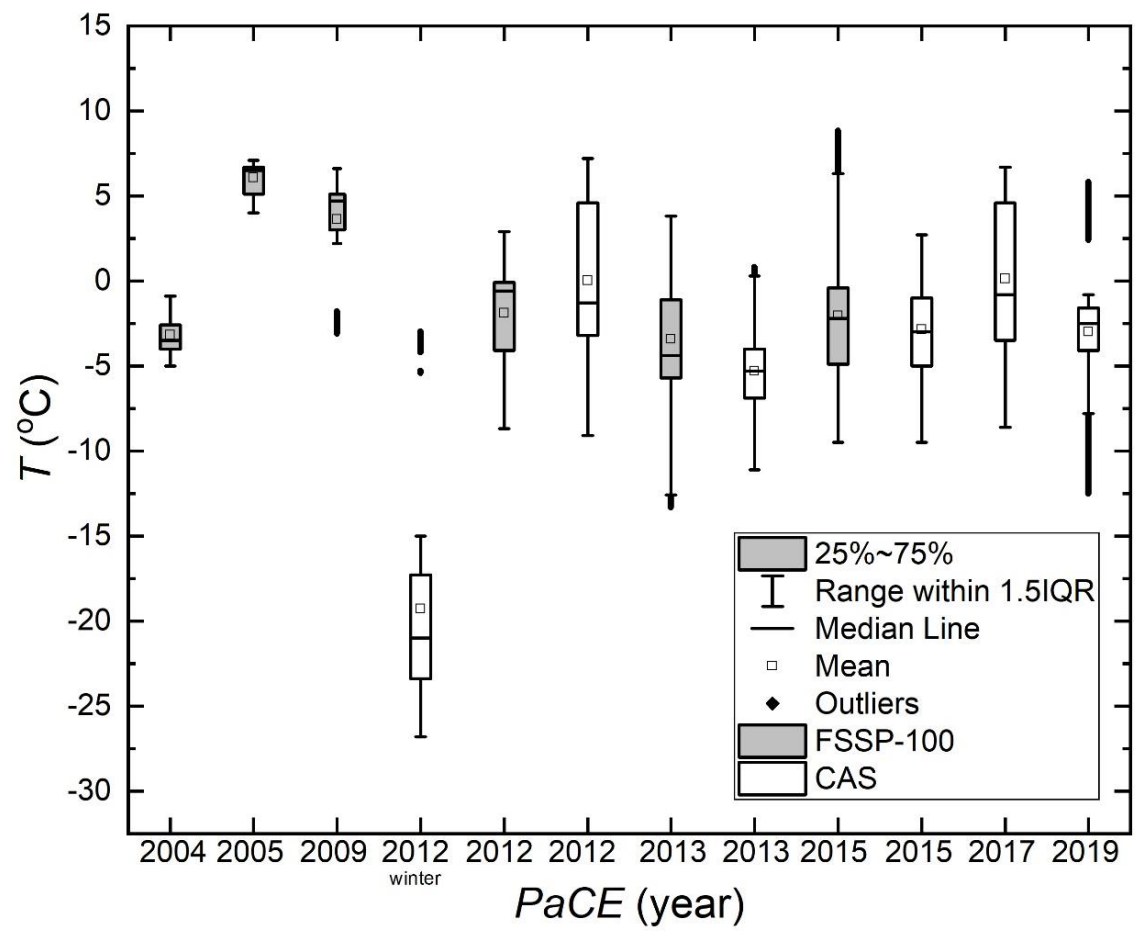

Figure 5. Statistical description of the temperature at 570m above MSL for each PaCE campaign when the FSSP-100 and CAS ground setups were operative. 


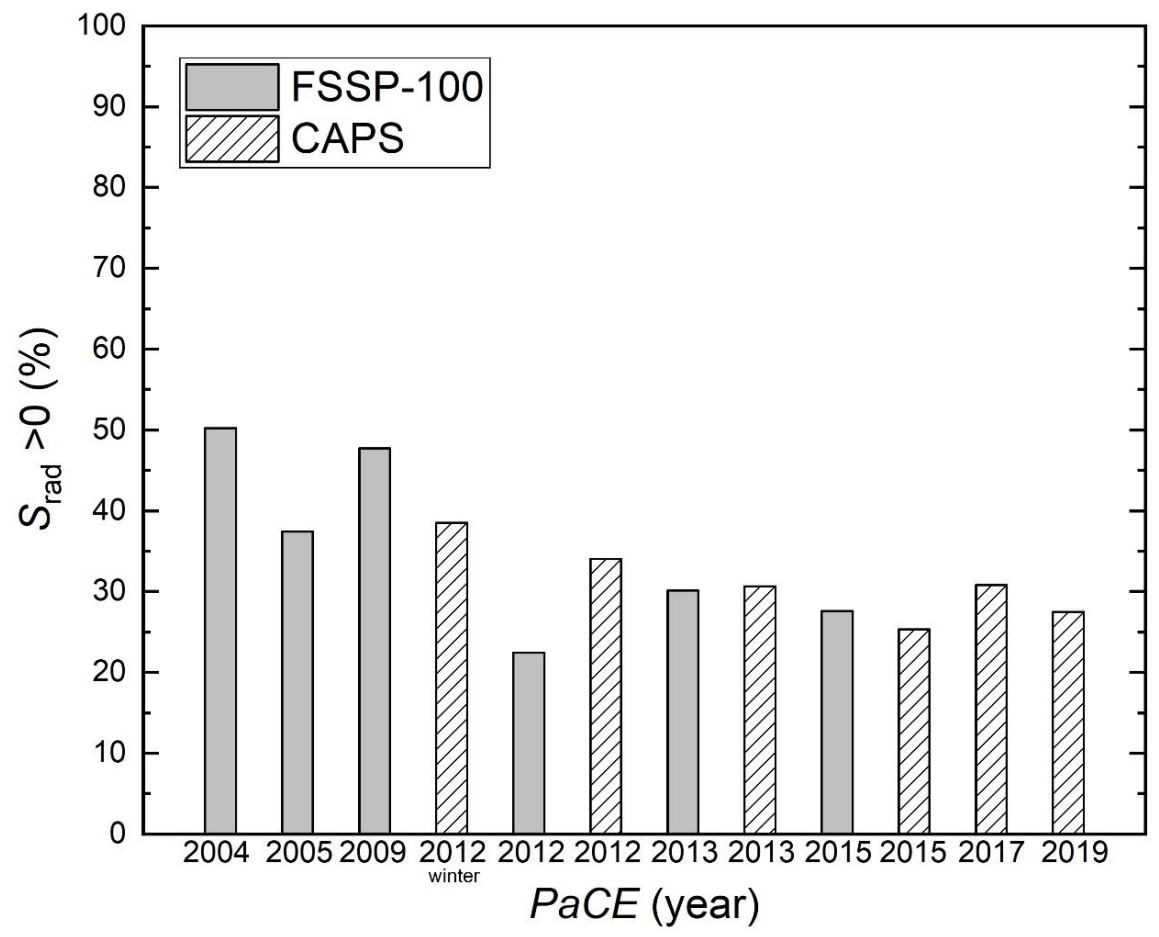

550

Figure 6. The percentage of the global solar radiation that was more than 0 during each campaign when the FSSP-100 and CAS ground setups were operative. 


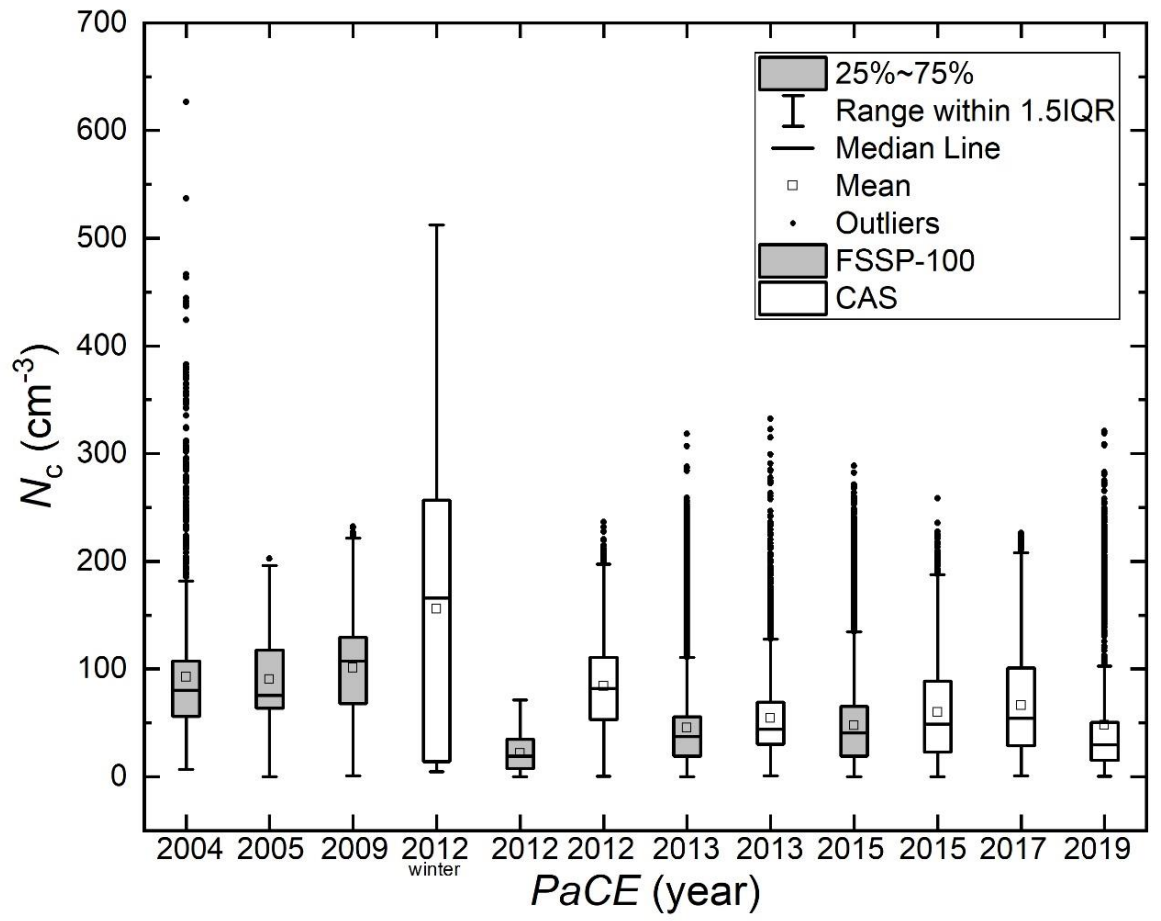

560 Figure 7. Statistical description of $N_{\mathrm{c}}$ for each PACE campaign during the FSSP-100 and CAS ground setups were operative. 


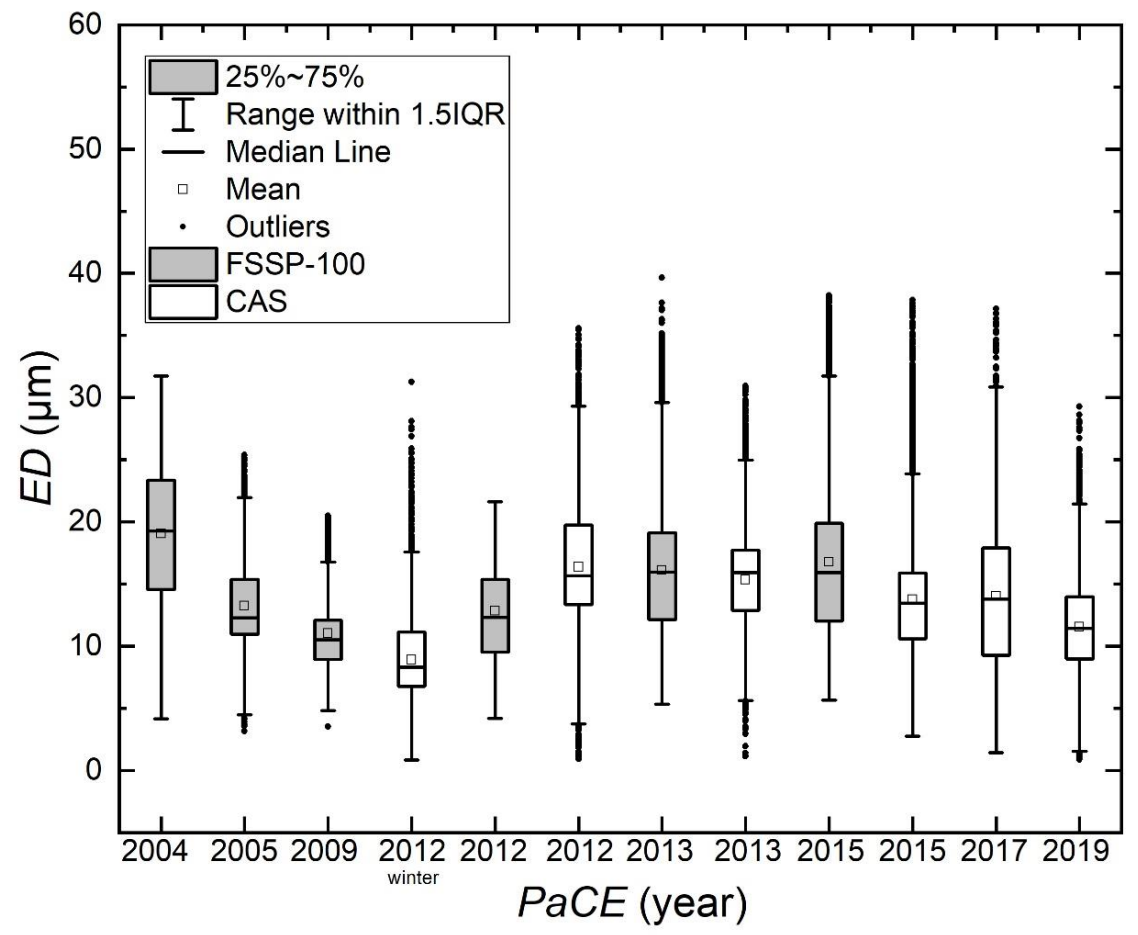

Figure 8. Statistical description of $E D$ for each PACE campaign during the FSSP-100 and CAS ground setups were operative. 


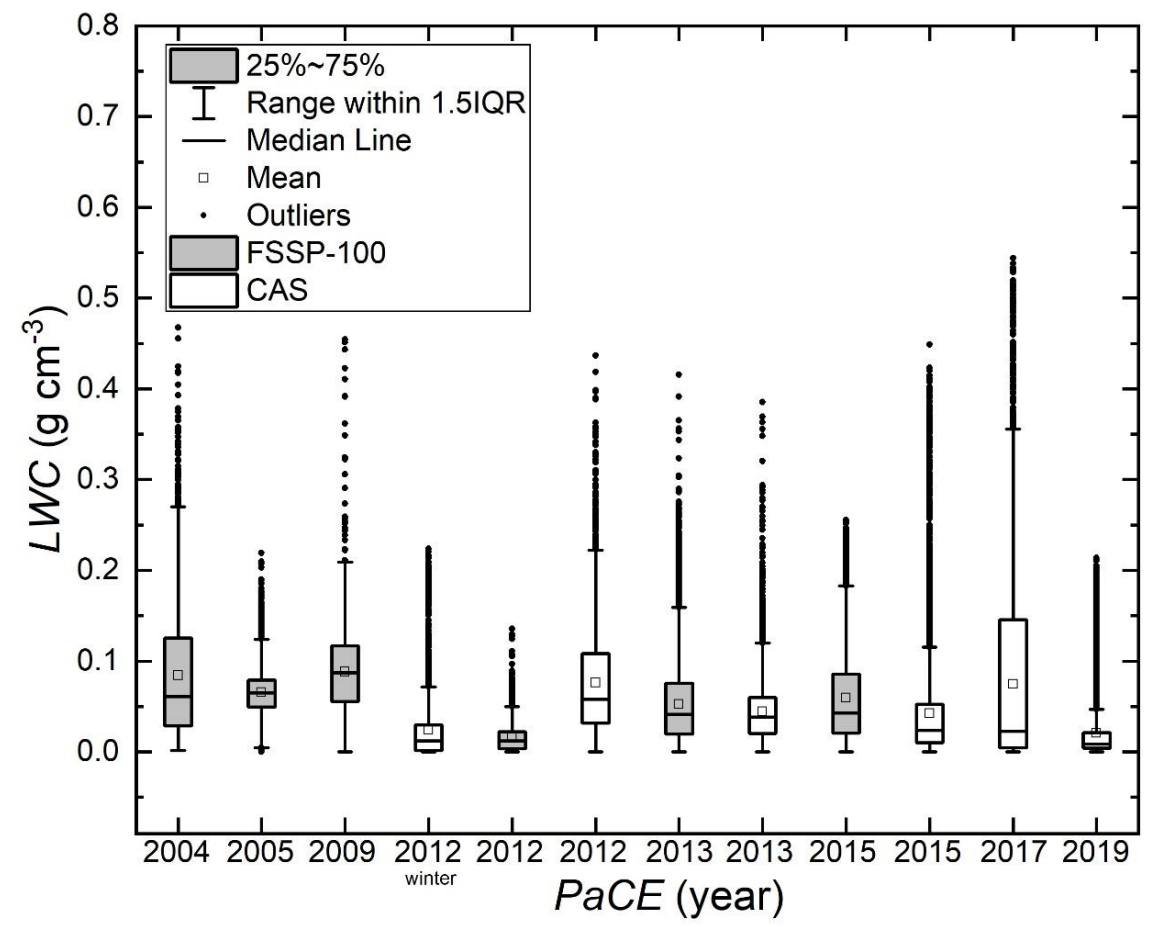

Figure 9. Statistical description of $L W C$ for each PACE campaign when the FSSP-100 and CAS ground setups were operative. 